\title{
RE-DISCOVERING THE IMPORTANCE OF CITIZENSHIP THROUGH IMMIGRANTS' EXPERIENCES: NATURALIZATION AND POLITICAL INTEGRATION IN PADUA, ITALY
}

\author{
Eriselda Shkopi ${ }^{1}$ and Zana Vathi ${ }^{2}$ \\ University of Padua, Edge Hill University
}

\begin{abstract}
This paper focuses on processes of political integration for immigrants in the Italian context, constituting as it does an understudied topic. It does so by looking at one specific community, Albanian immigrants, who have been typically heavily stigmatized. While Albanian immigration in Italy has been a focus of previous research, no consideration so far has been given to naturalization and its influence on other political processes at the level of immigrants' daily lives. Through the meanings which participants of this research attribute to citizenship and their acting as political agents, the paper unpacks the relations between this "status passage" (Glaser and Strauss 1971) and the political integration of immigrants. The findings show a very complex picture in which multiple factors and interactions play an important role. Legally speaking, Italian citizenship is a pre-condition for immigrants to enjoy the right to vote in elections at all levels, which participants considered a significant indicator of their political integration. Therefore, the political integration of immigrants is heavily conditioned by naturalization, which gives access to political rights, voice and representation as regulated at the state level. However, when considering the role of age and social capital in processes of political integration, there is also reason to believe that the political mobilization and participation of the youngest and most well-educated participants is not as exclusively attached to such formal recognition as a political subject.
\end{abstract}

Key words: political integration, citizenship, Albanian immigrants, Padua, Italy

\footnotetext{
${ }^{1}$ Eriselda Shkopi is PhD Candidate at the University of Padua, in Sociology. Her research concerns the naturalisation and political integration of immigrants of Albanian origin in Padua (Italy) and London (UK).

${ }^{2}$ Dr. Zana Vathi is Reader in Social Sciences at Edge Hill University, UK and specializes in migration studies.
} 


\section{Introduction}

A significant body of research exists on immigrants ${ }^{3}$ of Albanian origin, particularly in Southern Europe, and their identifications, socio-economic integration and stigmatization in relation to the receiving country ${ }^{4}$ (King and Mai 2009; Romania 2004; Vathi 2015). However, naturalization ${ }^{5}$ processes and the political integration of this collectivity have often been overlooked. Based upon an explorative study of citizenship and the political integration of naturalized first-generation Albanians, this paper analyzes how participants perceive and experience naturalization as Italian citizens and the acquisition of associated political rights. How such naturalization intersects with other pathways of political integration within Italian society is then explored. Research for this paper was based on qualitative methodologies - a different approach to the study of political integration, which is often studied by means of quantitative instruments. The central questions this paper seeks to answer are:

- How do naturalized Albanians experience the gaining of Italian citizenship?

- Does naturalization impact political integration and, if so, how?

- What are the meanings and motivations behind electoral participation?

This paper focuses on electoral participation since this is strictly linked to the status of citizenship in Italy, but other forms of political participation are also analyzed. Moreover, considering the role of locality and regionalism in Italy in terms of integration policies and practices and strategies of immigrants and minorities (Perocco 2003; Vathi 2012), the paper focuses on Padua, a city in the Veneto Region in the north east of Italy, without underestimating the national political structure and its impact on the local one.

The following sections provide contextual information and outline the theoretical framework used, followed by an overview of the study's methodology. Empirical sections analyze the main findings, before final considerations are turned to in the discussion and conclusion.

\section{Background and context}

Immigration, citizenship and political rights

\footnotetext{
3 The term immigrant as used in this paper refers to people born outside of Italy or those who immigrated to Italy after the age of 12, who may have experienced different migratory/return experiences in their lifetime, but were settled in Italy at the time the interview took place.

${ }^{4}$ As described by King and Mai (2009), Albanians' portrayal in Italy constitutes a unique case for its extreme stigmatization by the host society. The process of criminalization of Albanians, which took place in particular after August 1991, and continued until the beginning of 2000s, saw them associated with drugs, prostitution and human trafficking and savage behavior - a process fuelled by both politicians and the media.

${ }^{5}$ In this paper, we use the term naturalization also for those who applied on the basis of jus sanguinis, since these participants first entered Italy as immigrants with a permit of stay and later could apply for the Italian citizenship, having Italian ancestors. Baubock and Wallace $(2010,2)$ define naturalization as "any acquisition after birth of a citizenship not previously held by the person concerned that requires an application to public authorities and a decision by these".
} 
According to the Caritas/Migrantes annual report, the total number of foreigners residing in Italy as of December 31, 2015 was 5,026,153 or $8.3 \%$ of the overall population. The three main communities represented in this figure were Romanians (22.9\%), Albanians (9.3\%) and Moroccans (8.7\%). The latest statistics report that 178,035 immigrants became naturalized in Italy in 2015. Albanians were the largest group $(35,134$ naturalizations) followed by Moroccans $(32,448)$ (Caritas/Migrantes 2016).

Naturalizations have been consistently on the rise ${ }^{6}$ for a number of years, since 2010, indicating a strong tendency of immigrants toward settlement. The first large-scale influx of immigrant arrivals in Italy date back to 1991 when many Albanians arrived. Albanians now represent the largest immigrant community in Italy among non-European-Union (EU) immigrants, estimated to amount to 491,240, and are also described as one of the most integrated communities (King and Mai 2009). However, despite the significant demographic and socio-cultural changes as a result of immigration in the last 25 years, Italy's citizenship law has not changed since 1992. Moreover, based primarily on the jus sanguinis principle, it does not favour those who apply as long-term residents who need to demonstrate 10 years of continuous residence and fulfil several economic requirements.

Italy's immigrant population has reached $8.3 \%$, which is close to the average of other immigrantreceiving EU countries such as Germany, France and the UK (Eurostat 2014). However, the overall situation with immigrants' political rights in Italy differs significantly from those countries (e.g. The Netherlands, Sweden, Norway) where immigrants enjoy political rights at the local level even before naturalization. ${ }^{7}$ In Italy, political rights at all levels are regulated by Article 48 of the Italian constitution and are granted exclusively to Italian citizens, making citizenship constitute a clear boundary of the political community.

\section{Governmental and political personalities}

Until very recently Berlusconi's right-wing populist party Forza Italia (People of Freedom) dominated the political arena in Italy Berlusconi led different governments in coalition with Lega Nord (Northern League), a predominantly xenophobic party (Mantovan 2013) between 1994 and 2011, with only a few interruptions. After a technically "no party" government was appointed by the president between 2011-2013, none of the political parties were able to achieve the required majority of votes for winning the elections which resulting in political instability in Italy. From 2014 to 2016, the government was led by Matteo Renzi. At 41 years old he was the youngest leader in Italian political history which was perceived as a very positive change after the Berlusconi era. Renzi's political legitimization increased after the 2014 elections for the European Parliament, which he won by 40\%. On December 5, 2016, Renzi resigned after the results of the referendum on constitutional reforms (which took place the day before). He was replaced by Paolo Gentiloni from the same Democratic Party.

\footnotetext{
${ }^{6}$ Citizenship acquisitions tripled in the last 5 years: in 2010 there were 59,369 naturalizations, in 2011 56,148, in 2012 65,383, in 2013 100,712, in 2014 129,887, in 2015 as mentioned above there were 178,035 naturalizations.

7 For on overview of political rights granted to immigrants in the European context, please see the Migration Integration Policy index (Mipex): http://www.mipex.eu/political-participation accessed 27.03.2016
} 
However, Renzi represents a controversial personality, both appreciated and hated by Italians (Diamanti et al. 2015). The institutional reforms of his government are not universally accepted. His political personality has been equated with the Berlusconian model, which links to what Calise (2010) has called the amplification of the "personalization of politics". ${ }^{8}$ In this political and economic landscape, a new political movement, ${ }^{9}$ known as the Movimento 5 Stelle (5 Stars Movement) emerged. Created in 2005, the movement is led by the Italian comedian Beppe Grillo, has been since grown and mobilized people mainly through online forums.

\section{Padua}

As of 2014, Padua had 211,210 inhabitants, 33,268 of whom were immigrants living in the city with a permit of stay (Comune di Padova - Settore Programmazione e Statistica 2014). Albanians are among the largest non-EU communities, with 1,605 residents after the Moldavians $(4,865)$, Chinese (2,345), Nigerians (2,653), Filipinas (1,941) and Moroccans $(2,001)$. Furthermore, they constitute the second largest community in the last three $y$

ears in terms of citizenship acquisitions. In Padua, naturalizations at the local level converge with national-level indicators, according to which Moroccans and Albanians are the two largest naturalized groups.

Padua constitutes an interesting research context on the basis of the municipal elections that occurred in the city during May 2014, when research for this paper was conducted. At the time of these elections, the electorate in the city of Padua amounted to 163,393 eligible voters, 289 of whom were Albanian-origin immigrants with Italian citizenship. No data exists on the voting preferences of this group either at the national or local level.

The municipal elections were won by a centre-right coalition led by Massimo Bitonci, representative of the aforementioned xenophobic party Lega Nord. This was a radical change after more than 15 years of a centre-left administration in the city an interval between 1999 and 2004 aside. Mayor Bitonci was quick to exclude immigrant voices and political representation. By way of example, on the first meeting of the new town council (June 20,2014), there was no seat reserved for EgiCenolli, the president of the Commission for the Representation of Foreign Citizens.

8 Calise considers this a worldwide process, which became widespread during the $20^{\text {th }}$ century when big political ideologies decreased. In the Italian context, political choices are made based on the candidate's qualities and characteristics. Therefore, street politics and big ideologies have been substituted by the "politics of image". In Calise's analysis, Berlusconi embodies the extreme side of the personalization of politics. Calise 2010, 7-9.

9 Grillo's 5 Stars Movement is an anti-European, anti-establishment movement. It offers a radical and popular opposition to the Italian government and has similar agenda to parties such as Podemos in Spain and, to some extent, Syriza in Greece. 


\section{Framing immigrants' political integration and its links with naturalization}

The political integration of immigrants is a growing research topic on both sides of the Atlantic. In the European context, scholars started to tackle the issue in the late 1990s (Morales and Giugni 2011). It is worth noting that conceptualizations and operationalizations of political integration differ significantly between continents and even within the same context. Often scholars address political integration as just one dimension of integration together with social and economic integration (Chaudhary 2016). Other authors underline how migration researchers and scholars of political participation could both benefit from a closer dialogue relating to the political participation of immigrants (Bloemraad and Schönwälder 2013). With respect to the European context, Martiniello offers one of the seminal definitions of political integration:

In a broad sense, political integration has four dimensions. The first dimension refers to the rights granted to immigrants by the host society. One could say that the more political rights they enjoy, the better integrated they become. The second dimension is their identification with the host society. The more immigrants identify with the host society, the better their political integration. The third dimension refers to the adoption of democratic norms and values by the immigrants, which is often presented as a necessary condition for political integration. Finally, immigrants' political integration involves political participation, mobilization and representation $(2005,2)$.

Martiniello's definition grasps the nature of political integration as a social process, located in the interaction between structure and agency, which at the same time shapes other dimensions, such as feelings of identification. Moreover, it utilises political integration as an umbrella term by considering a range of activities both electoral and non-electoral in form, such as lobbying and mobilization but also representation. However as we will discuss in the empirical sections, Martiniello's definition is not without controversy, in particular concerning points two and three.

In the European context, empirical research has underlined the influences of citizenship regimes on immigrants' political integration. Recognizing the role played by local policies and institutions, this approach stresses how the national political opportunity structure (POS) is more decisive than the local one. Since formal citizenship is part of the countries' philosophy concerning immigrants inclusion/integration politics, even in countries where political rights at the local level are granted, restrictive citizenship regimes may lead to "exclusionary messages" (Gonzales-Ferrer and Morales 2013) towards immigrants and consequently to lower electorate turnouts in local elections.

While there are debates about the links between political integration and citizenship and their operationalization, electoral turnouts are largely used to measure the health of the political integration of immigrants (Dancygier and Saunders 2006). Another dimension that needs attention is the distinction among (non) conventional forms of participation. Political participation has been traditionally defined as voluntary activity undertaken by ordinary people in order to influence, directly or indirectly, political outcomes at various levels of the political system (Verba et al. 1995, 
38-39). While conventional forms are those activities that pertain to the electoral process (e.g. contacting a politician and participation in the electoral campaign), non-conventional electoral forms are defined as "extra-institutional" activities of direct political action such as protesting or signing a petition (de Rooij 2012).

The focus on electoral activities is important since they constitute the gateway to having a political voice, to being represented and to participating when important decisions are made on immigration policies (Boccagni 2012). Further, voting is considered as one of the most meaningful acts in which citizenship is embodied and displayed (Bueker 2005), and one of the most fundamental political acts in a democracy (Putnam 2000). Substantial research has focused on immigrant voting in the European context. ${ }^{10}$ In her seminal research Togeby (1999) found that immigrant groups in Denmark had the same shares in electoral turnouts as Danish natives. She also found that differences among immigrant groups (mainly between the Pakistani and Turkish communities ) in the same local context were due to each group's collective mobilization on the basis of ethnicity, as well as the role played by local political agencies in not being conducive toward immigrants' political mobilization.

More recently, de Rooij (2012) and Sandovici and Listhaug (2010) explored the differences in patterns of political participation among immigrant-origin populations in comparison to native populations. While voter turnouts is not significantly lower among immigrants compared to natives, the differences observed within immigrant groups has depended on language command and length of residence in the receiving country. However, these differences within the same ethnic group are not explored in depth by any previous research. Indeed, in migration studies there is a tendency to see immigrants as homogeneous ethnic groups and "within-group" differences are not studied in depth (Glick Schiller 2012, 521). This is also the case of studies of political integration, and to a large extent, also studies of voting.

More helpful in this respect is research that explores the political behavior of immigrants in order to unpack the links of voting with socio-economic variables, and with "ethnic identity" or "groupbased interests". Dancygier and Saunders (2006) explored the political preferences of immigrants in Germany and Britain and found that it is not only individual characteristics that matter for elaborating voting preferences (socio-economic-status - or SES model); the receiving local context matters as well as one's "identification with a collective group interest" (citation). Further, it appears that the "impact of the immigration experience itself may be more important in socializing immigrants to the host country than the length of their stay" (Dancygier and Saunders 2006, 978). This goes against theories that maintain that political assimilation occurs over time (Gordon 1964).

This paper seeks to address some of the limitations of these approaches, seeking to integrate existing literature by looking at the processes behind the political integration of Albanian immigrants in Italy, particularly in Padua. This topic cannot be studied without analysis of the

\footnotetext{
${ }^{10}$ Togeby's (1999) study in Denmark was conducted in two municipalities, Copenhagen and Århus, she analyzed data on electoral turn-out of foreign nationals with a permanent residence permit from at least three years, and focused mainly on Turkish and Lebanese immigrants. Fennema's and Tillie's (1999) work focused on Moroccans, Surinamese, Antilleans and Turks in Amsterdam.
} 
elaboration of stigma ${ }^{11}$ as part of the integration process of Albanians in Italy. However this paper sidelines the origins of stigma or stigmatization processes per se, since a substantial literature has already examined the stigmatization of Albanians in Southern Europe (King and Mai 2009; Vathi 2015). Indeed, for Albanians in southern Europe, particularly in Italy and Greece, stigmatization has played a prominent role in forging assimilation processes. ${ }^{12}$

\section{Political integration of immigrants in Italy}

In most Western European countries, scholars started to address immigrants' political subjectivities in the late 1990s (Martiniello 2006; Però and Solomos 2010). However with the exception of a few isolated initiatives (e.g. Caponio 2006), Italy only began to address this issue during the last decade (Boccagni 2012). Following scholarship developed in Western Europe, scholars in Italy have increasingly focused on institutional, discursive and organizational opportunity structures (POS). POS refers to both top-down openness for participation opportunities (Della Porta and Diani 1999) and to an overture at the local level, with a focus on power relations and party systems and their role in involving immigrants (Garbaye 2004). Cinalli et al. (2010) compared POS in nine European cities and confirm what other scholars (de Rooij 2012) have found at the EU level. They found that political participation is greater among immigrants with higher education levels, language proficiency and long-term residence, and in cities where the institutional and discursive opportunity structures are more accessible (Cinalli 2010). Despite the effects of personal resources disposable to immigrants, POS dominates in influencing the political participation of immigrants.

In the Italian context, cities and different regions are characterized by distinct local identities and often differ in terms of local politics (Borket and Caponio 2010). Pilati (2010) studied immigrant's political integration by looking at POS in Milan, which rated as having the lowest level of immigrant political participation when compared to other cities in Europe. Accordingly, "the organizational integration model that regulates the political participation of immigrants is oriented toward an assimilation model, in which political integration takes place mainly through the incorporation of immigrants within forms and modalities that dominate in the host society" (Pilati 2010, 275)). ${ }^{13}$ Additionally, among immigrants in her sample, the delayed citizenship attainment (waiting more than 10 years) seems to influence a kind of habitus of non-participation (Pilati 2010,).

\footnotetext{
${ }^{11}$ Link and Phelan (2001) proposed a revised definition of this concept, by maintaining that there is stigmatization when the following five interrelated "components" are all present: labelling, stereotyping, separation, status loss, discrimination.

${ }^{12}$ According to Gordon (1964), assimilation is a process involving at least seven subprocesses. Acculturation is likely to be the first kind of assimilation to occur and may take place also when other types do not, while structural assimilation is seen as the key point to which other kinds of assimilation naturally follow. Starting from this model, King and Mai (2009) found a model of a rather asymmetric assimilation of Albanians in Italy. While Albanians nurtured a kind of italophilia towards the Italian, Italians cultivated a kind of albanophobia toward Albanians. This severe stigmatization is viewed as having led Albanians in the late 2000s to several forms of assimilation, going from radical assimilations, to encrypted or reactive Albanian identity, to mimesis with Italians (Romania 2004).

${ }^{13}$ Translated by authors.
} 
These studies are very important for having unlocked the discussion on this subject, however they are not exhaustive. As Mollenkopf suggests in order to unpack political integration the role other actors play in the political processes and the situation on the ground need to be addressed otherwise we risk resorting to "structural functionalism" (Mollenkopf 2013, 113). Due to these seminal empirical works in the Italian context, however, immigrants are no longer seen solely as a workforce or as passive victims - views already criticized by Martiniello (2005) — but also as bearers of political subjectivity. ${ }^{14}$

\section{Methodology}

This paper is part of a larger study on belonging, identities, naturalization pathways and the political integration of naturalized Albanians conducted by Eriselda Shkopi. Considering that most research in the field has focused on formal activity/expression of political integration (i.e., elections), this paper focuses on another important yet unstudied aspect: motivations and meanings that derive from everyday interactions in the context of naturalization and overall political integration. In order to achieve this, qualitative methodology and precisely grounded theory ${ }^{15}$ were utilized for the purpose of data collection, coding and analysis.

The sample for this paper consisted of 30 participants with two subgroups of interviewees: 20 naturalized immigrants and 10 key actors. The interviews with immigrants consisted of life stories and were conducted in Padua, and followed a dialogical approach (Markova 2008 ${ }^{16}$; La Mendola 2009). A list of topics was prepared, in order to guide participants during the narration from general frameworks to specific episodes. The relatively small number of cases has to do with the fact that the dialogical approach and life stories are time-consuming, both in terms of conducting the fieldwork and the analysis. The sample number was also impacted by participant withdrawals

In terms of recruitment, two strategies were followed: gatekeepers (intercultural mediators) and snowballing. Participants of the larger subgroup (20) were expected to be first-generation immigrants; hold Italian citizenship; and not be involved professionally in politics.

The sample was well balanced concerning gender, class and age, as well as province or provenience of Albania from which participants originated. The average participant age was 44, ranging from 32 to 63 . The average time spent in Italy was 18 years. In regards to education, 11 out of 20 participants had concluded university studies either in Italy or Albania. Their current professional backgrounds varied from musician, security guard, businessman/woman, cleaning lady, tradesmen, senior centre coordinator, IT technician, stay-at-home mother, retiree and

\footnotetext{
${ }^{14}$ Krause and Schramm $(2011,118-119)$ define political subjectivity as follows: "When we talk about political subjectivities, we have two things in mind. First, we want to draw attention to the practices through which political subject-positions come into being. These entail practices of inclusion or exclusion (as they are often emphasized in citizenship debates), but also dimensions of longing and desire (as they are expressed in belonging)."

${ }^{15}$ According to Flick $(2009,16)$, "the goal of your research then is less to test what is already known (e.g., theories already formulated in advance), but to discover and develop the new and to develop empirically grounded theories".

${ }^{16}$ According to Markova $(2008,83)$ "I refer to the theoretical approach that is known as dialogicality. This approach is based on the triangular relations of Ego-Alter-Object". Here Ego is the interviewer; Alter is the interviewee, and Object is the themes on which Alter is invited to narrate.
} 
unemployed.

This data was combined with 10 semi-structured interviews with key actors, mainly individuals professionally involved in politics or community activists, from different cities ${ }^{17}$ Within this subgroup, six were Albanians with Italian citizenship, two were Albanians with only Albanian citizenship, and two were native Italian citizens. The narratives of key actors provided information on the situation in other localities and POS at country level, mainly concerning opportunities for immigrants to be included and recognized as political actors. Interviews lasted from a hour and a half to three hours. The interviews were recorded (apart from the case of one interviewee who did not agree to this) and then entirely transcribed. All the participants of the main group are cited using pseudonyms, whereas those in the key actor group are referred to by their real name.

The data was analyzed following a grounded theory approach. The first two cycles of open and focused coding were computer-assisted (Atlas.ti), while the final stage of analysis was manual and based on hardcopy transcripts, in order to better contextualize categories within the narratives. ${ }^{18}$

Even though this exploratory study could inform the debate on citizenship and political integration of immigrants, one limitation is that it focuses on one immigrant group. Therefore the data cannot be representative either for Albanians, due to the small sample size, or for other immigrant groups in Italy. This is particularly important since previous research has shown (King and Mai 2009; Vathi 2015) that Albanians have a particular integration history in Italy, which demonstrates a strong tendency toward assimilation.

\section{Naturalization and political integration of Albanians in Padua}

\section{Citizenship: meanings and experiences}

What does gaining Italian citizenship mean to our participants? Similar to the findings of research by Colombo et al. (2009) on the second generation of immigrants in Italy, for the first-generation Albanian immigrants we spoke to, citizenship encapsulates multiple meanings and feelings. Albert, a 38-year-old man who has been an Italian citizen since 2010 and a resident in Italy for 19 years, referred to himself as clandestine before gaining Italian citizenship through the pathway of longterm residence. His choice, as with many others, seems to have been motivated primarily by the precarious legal status immigrants experience in the country:

The day I completed the ten years for the indefinite leave to remain, I brought my application to Vojsava (Albanian cultural mediator in the city council) (...) When I applied, the girl at the office told me "but wait at least 24 hours, didn't you sleep last night?". I was looking forward to it with joy and anxiety, to finally have my right.

\footnotetext{
${ }^{17}$ The subgroup of key actors was composed of activists living in different cities in Italy: 1 in Padua; 1 in Treviso; 3 in Rome; 1 in Firenze; 1 in Montegrotto-Padua Province; 1 in Milan).

${ }^{18}$ Atlas.ti was employed for the general study's sample of 75 interviews, since interviews with different groups took place in Italy and the United Kingdom. Further analysis of the data was based on hardcopy transcripts in order to have an integrated understanding of each narration.
} 
Being discriminated [against] when you don't have documents (i.e. citizenship)... you cannot do this, you cannot do that, you cannot buy a car, you cannot get a mortgage... It's also true that when you have documents (i.e. the passport) you also have more... you're legally more controlled; like everything else, it has good things and less good things, but you cannot stay a clandestine all your life!

Thus, citizenship emerges as an award after a long and difficult pathway. Participants see it as a formalization of their relationship with the state, both in terms of rights and obligations (Lister et al. 2003). Nevertheless, a common pattern of participants' narratives was a kind of naturalization without recognition by Italian society, one that hampers the full realization of the second dimension of Martinello's model of political participation: identification with the host society. As Skender (male, 42), who has been an Italian citizen since 2004 (via jus sanguinis, as a descendant of Italians) and a resident since 1992, explains below, the divide of Italians and perceived "others" is still evident:

In your opinion, what do you represent to Italy?

(silence)... A normal person like others...that maybe...when he doesn't have a job, is a problem; when he has a job and doesn't speak up... is more welcome. (...) The problem is that it is becoming normal that in times of crisis the foreigner becomes visible. Maybe we feel it more, that we are still foreigners, not $100 \%$, but still with that old mentality; even though many years have passed, you have it inside you, this hurts inside you, "the foreigner"...

Skender's words demonstrate a deeply rooted positioning by Italian society, of immigrants —even those who have been naturalized - as stranieri (strangers). ${ }^{19}$ In this profile, the detachment from the country of residence, seems bolstered by the heavy stigmatization this collectivity has endured in Italy. In the same vein as Skender, couple Lule and Marsel, residing in the country respectively for 16 and 21 years, spoke about the disempowerment caused by the stringent rules for gaining citizenship, the processes lack of transparency, and also because of the fear that they may be rejected by the institutions. Anila Husha, an Albanian woman who holds Italian citizenship and acts as the vice president of the Albanian-Italian Association "Occhio Blu" in Rome offered insights into how immigrants are perceived by Italian society after naturalization:

Does anything change in the lives of the immigrants after they gain Italian citizenship?

...Hhm, no because in the eyes of the Italians you are always a foreigner; even though you say you have Italian citizenship, you remain a foreigner. We know an Albanian who is an Italian citizen and has lived here for more than 40 years and Italians still call him straniero [stranger]; it is not easy for the mentality of the Italians. It is us who feel we belong and consider ourselves Italians now [that we gained citizenship]. This is my impression and I work in Italian institutions; I know the situation from the inside.

${ }^{19}$ Italian for foreigners. 
Again similar to the findings of Colombo et al. (2009), citizenship to our participants means also being integrated, not feeling excluded, and being recognized as equals. For Jeta and Kushtim, a couple who have resided in Italy since the late 1990s and who have been Italian citizens since 2009 and 2012 respectively, citizenship means an emotional and important step toward integration:

\section{How did you experience receiving citizenship?}

Kushtim (male, 63): We were waiting for it anxiously; when I got it, I was in tears; Jeta was there, in the town council with me...

Jeta (female, 60): [I feel like] a person who decides on her choices. [With citizenship] you're integrated; when you think you will live here, it comes naturally (...) You do not feel excluded from society; even when we didn't have it [citizenship] we felt equal to them [Italians].

Therefore, holding Italian citizenship helps immigrants avoid possible deportation and a precarious legal status. However the formal recognition by citizenship does not seem powerful enough to counter the negative perceptions and social labelling of immigrants as foreigners by Italian society. Nonetheless, individual naturalized immigrants may have multiple experiences and benefits from this "status passage" (Glaser and Strauss 1971) based on the rights citizenship affords. For instance, the gaining of citizenship is considered by some as an investment or as an entryway to sustain the social and spatial mobility of the family in Italy while othersmay perceive it as a keystone to protect and maintain emotional and affective relationships. For a 65-year-old immigrant that participated in this study, having Italian citizenship meant being able to continue to stay closer to his children who live in Italy, or to follow them wherever they might move in case of a re-migration.

To conclude this section, holding citizenship, as Jeta (female, 60) says, means also "to not feel excluded". This is fundamental in relation to conventional political rights, since these are extended only to Italian citizens, at the local and national levels. The next section analyzes dimensions of inclusion/exclusion in depth, including the implications of not having citizenship status, as well as individual motivations behind voting, and resources and convictions that nurture or hamper political integration.

\section{Political integration: rights, meanings, motivations}

A significant change in participants' lives on gaining Italian citizenship was securing the right to vote in elections at all levels. By giving the right to vote to immigrants, citizenship has the power to challenge what Perocco has called "the Italian apartheid", a process that strengthened in particular after the passing of the Bossi-Fini law (nr. 189, 2002). This law aimed to reduce immigrants and community leaders to a mere workforce, denying any human, social, cultural, or spiritual aspect to their subjectivities (Perocco 2003). Jeta (female, 60) clearly speaks about this sense of not having a political voice:

... when there were the primary elections [of the Partito Democratico] you felt increasingly left out ... Thinking that all those years you've spent your life here, with 
friendships and with... all the problems that life brings, you feel a little excluded. We had the pleasure to... [vote]. It's something very exciting and how I can tell you... a pleasure and a duty at the same time. As a person who lives here... I too felt I had my rights, even if blood is what it is, the origins are those that are [Albanian]...

Therefore, citizenship and the consequent access to conventional electoral political rights means first and foremost a "right to have rights" (Arendt 1973). The situation of Albanians in Italy prenaturalization resonates with the notion of "frozen" political subjectivities (Krause and Schramm 2011).

In Italy, the right to vote at all levels is strictly linked to Italian citizenship, while Albania, the country of participants' origin, does not allow its citizens to vote from abroad. Once past this gateway, participants show a higher inclination to stay updated through television, newspapers and social networks about political life in Italy. They have also taken up other forms of political participation such as attending political meetings before the elections, writing to a parliament or a local constituency member, or going on strike.

Having access to conventional forms of political participation bears multiple meanings. To our participants voting means "making a contribution", fulfilling a civic obligation, holding a powerful instrument for influencing a positive change in the country. Moreover participants' narratives show how acting as political actors and making a political choice - who to vote for-is informed both by mainstream political debates and individual political convictions and values:

Doriana (female, 55): I felt it was a duty to go and vote. I'm really concerned about how things are going in Italy, and whatever my vote matters, together with others, I try to give my contribution so that the right person gets elected... Grillo, no! Renzi,...yes! I supported him; let's see what he will do.

For older participants in the sample group, a reduction of non-conventional forms of political participation also occasionally emerged. What these first-generation immigrants narrate, in relation to non-electoral forms of political participation, could be framed as "non-participation habitus" ${ }^{20}$. This is due to two main considerations. For some participants, citizenship status primarily means economic and social stabilization, regularized work and the end/reduction of exploitation by their employers which was a common experience in their first years of residence in Italy. Therefore, lack of availability of time, money and social networks have played an important role in discouraging political activities for this group. For other participants, holding Italian citizenship means not risking deportation for behaviours considered against public security (Just and Anderson 2012).

\footnotetext{
${ }^{20}$ As Pilati $(2010,275)$ found in her research in Milan, the long journey to citizenship seem to bring also some of our participants to a sort of resistance toward political participation. In other terms, immigrants incorporate this not recognition as political actors and do not participate also after obtaining citizenship.
} 
For Hena(female, 51), as for other participants, the fear and the imminent threat of losing the financial security she has constructed with difficulty in Italy are important motivations behind voting. A link emerges between the fear of possible status loss due to the economic crisis and new immigrants (Cingolani 2012), and voting preferences that, combined with stigma management, affect participants' orientation toward populist or left-wing parties.

For instance, Hena is motivated to vote for Partito Democratico (Democratic Party) as a way of contributing toward political changes she feels are needed in Italy after years of Berlusconism.

Hena (female, 51): Other countries are dealing with this (migrant crisis) differently. Here in Italy ...what's this?! Where are all these people going?! Where will they eat?! My father was saying the same, "if a guest comes to your house, you will host them for 3-5 days, and then you will have to go out of your house yourself!". It is really worrying because we have tried this (migration) ourselves; but the way they keep coming here, can't the Italian state stop this through bilateral agreements with other states?! But nothing is changing, it just keeps getting worse!

Although not representative of all "new Italians" or immigrants with double citizenship, the data here counter what quantitative studies generally maintain for Italy (Pilati 2010) and other European countries (Gonzales-Ferrer and Morales 2013). Having been denied the right to vote for more than 18 years (the average length of stay for participants) and living in an assimilationist and antiimmigrant region seems to stimulate, rather than weaken or void, the meaning of electoral political participation for our participants. The majority saw electoral political participation as the recognition of being heard, having political voice, and influencing the policies of the place where they contribute economically, culturally, and also politically.

Voting also encapsulates symbolic dimensions and emerges as an important watershed in the coconstruction ${ }^{21}$ native-immigrants of belonging and as an act that plays both a symbolic and a substantive role (Zincone 2006). The act-ritual of voting itself seems to evoke feelings of being part of a political community (Pizzorno 1986, 372) ${ }^{22}$ and, in a circular way, to also nurture social bonding (Bueker 2005). However, even though immigrants are eager to vote and despite their participation, this does not correspond to how politicians perceive their political participation. Marco Paccioti, the coordinator of the Immigration Forum ${ }^{23}$, describes how the most progressive Italian party, Partito Democratico, deals with the issue of political representation and involvement of immigrants in Italian politics:

\footnotetext{
${ }^{21}$ On the one hand, the receiving society draws a boundary through naturalization and voting in terms of "who may/not belong to political community", and on the other, immigrants accept this boundary in Italy by not challenging it through lobbing, or claiming more politically inclusive norms.

${ }^{22} \mathrm{Cfr}$. "(..) Behind both types of reasons (voting or contributing to causes) there is always the common need of securing recognition for the identity of my successive selves" (Pizzorno 1986, 372).

${ }^{23}$ Immigration Forum - Forum Immigrazione - is organized by the Italian Democratic party to discuss issues related to immigration.
} 
Even within the party there is a difficulty in understanding a reality that is already changing but which often also in the newspapers is presented as a possibility, "if one day it will happen" while we already have 5 million immigrants. (...)

Thus, political agencies and their leaders have difficulties in accepting and recognizing immigrants as political subjects (Bloemraad et al. 2008; Però and Solomos 2010). In line with previous research (Cinalli et al. 2010; Pilati 2010), our findings go more in depth by displaying the coconstruction processes underneath a peripheral political positioning of the Albanian collectivity that in recent years is becoming increasingly visible, and claiming recognition of its members as political subjects. Albanian activists Anila Husha and Erida Perarla Cela, both stress that the low engagement and lack of mobilization of Albanians to raise issues concerning their rights should also be attributed to Albanian leaders' lack of experience with Italian parties and politics more broadly, and the fact that Albanians had first to invest in addressing their stigmatized visibility. Only in recent years, after reaching higher levels of socio-economic stabilization, could they allow themselves to also engage in political issues concerning both Albania and Italy.

A last interesting nuance within our sample that should be underlined is the experience of the youngest (under 45), and well-educated participants, for whom political integration is independent of naturalization.

\section{How did you become a member of a political party?}

Neritan (male, 40): ... I became a member before I gained Italian citizenship. I was still an Albanian citizen when Fini ${ }^{24}$ came to Padua for the first time; in 2006 I was the only Albanian registered on their computer. And I have met him after I gained Italian citizenship. "Are you Albanian?", he asked me. "Yes", I said, "my family from my father's side has been a supporter of your party, too" ...[...] It's not really that I am a crazy fan, but the day they won, after many years that we were waiting to get rid of the left, I joined the others at the Piazza.

It appears that political engagement and affiliation for Neritan and others of different political orientations consists of values and skills through which young participants were first socialized in the country of origin and then re-socialized in the context of residence.

This is also the case for the youngest Albanian activists, who were involved professionally in politics despite not having Italian citizenship. These profiles show how acting (or not) as political actors is both a result of interaction between structure and agency in the country of residence, but also in the country of origin prior to emigrating. Both the past political socialization and the individual integration pathway play an important role. These profiles further demonstrate how citizenship status is not necessarily a sine qua non to engage and even mobilize other immigrants through (conventional or unconventional) political activity.

\footnotetext{
${ }^{24}$ The founder of the right-wing party Alleanza Nazionale
} 


\section{Discussion}

In the Italian context, naturalization as a pre-condition to enjoy political rights at all levels is discriminatory for an important part of the population and, at the same time, it does not eradicate exclusionary messages even when immigrants finally become naturalized (Boccagni 2012, 93; Pilati 2010). Furthermore, in a country like Italy, where the political rights of immigrants are strictly linked to citizenship status, political integration encounters several barriers before realization. These include a very unfavourable normative and administrative procedure of naturalization and an unwelcoming attitude toward immigrants. However, the salience of the second and third dimensions of Martiniello's model for the Italian context, respectively "identification with the host society" and "adoption of democratic norms and values", are not fully supported by the findings. First, the younger and well-educated immigrants were involved professionally in politics even before holding Italian citizenship. Concerning the third dimension, not all immigrant collectivities move from non-democratic countries or have not been socialized with some democratic rules prior to migration. Most importantly, in assessing immigrants' democratic values against those of a host society, an important question arises: Can Western countries like Italy still be considered democratic despite the lack of political representation for long-term immigrants?

The same denial is omnipresent in the works of Italian political parties today, which rely on the activism of immigrants and increasingly on their vote, but do not recognize them as equal members of the electoral body, and ultimately, of their society. Indeed, Italian politicians may well be missing an opportunity to mobilize this immigrant group, considering the relatively large size of the Albanian community in Italy and their strong tendency to integrate in Italian society.

\section{Conclusions}

What does this study tell us about immigrants' political integration in Italy? This research contributes to the political and academic debate on immigrants' political integration in Italy and also in Europe (Bloemraad and Schönwälder 2013), and calls for further research and innovative approaches to study in order to overcome previous partial readings of the issue. Future studies should opt for comparative approaches without underestimating "within-group" differences across axes of gender, age, education class, provenience (rural, urban), and religion.

Even though our findings are not representative of all Albanians with the right to vote in Italy or of all naturalized immigrants, this paper offers original findings related to the meaning immigrants attribute to naturalization and political rights. Voting - taking part in the electoral process at all levels - emerges as a powerful means toward inclusion in the face of a missing political integration policy. Through its symbolic and substantial attributes, voting means having a political voice, being recognized as subjects and not objects of political decision-making processes, and being part of and belonging to a political community. These findings illustrate how in a hostile and unfavourable context, citizenship matters to immigrants (Bloemraad 2006) and provides both a secure legal status and the sine qua non for full and significant political integration. 


\section{Acknowledgments}

An early version of this work was presented at the 12th Annual IMISCOE Conference, Geneva: Rights, Democracy and Migration - Challenges and Opportunities, June 2015.

We are very grateful to the critical comments of the participants in the panel and to the editors of this special issue: Elke Winter and Anke Patzel. A special thank you also to the two reviewers for their stimulating comments. 


\section{REFERENCES}

Arendt, Hannah. 1973. On the Origins of Totalitarianism. New York: Harcourt, Brace, Jovanovich.

Baubock, Ranier, and Sara Wallace. 2010. Eudo Citizenship Policy Bried no. 2, "Naturalisation". http://eudo_citizenship.eu. Accessed May 6, 2016.

Bloemraad, Irene. 2006. "Becoming a Citizen in the United States and Canada: Structured Mobilization and Immigrant Political Incorporation", Social Forces, 85 (2): 667-695. http://www.jstor.org/stable/4494935. Accessed May 20, 2016.

Bloemraad, Irene, AnnaKorteweg, and GökçeYurdakul. 2008. "Citizenship and immigration: multiculturalism, assimilation, and challenges to the nation-state". Annual Review of Sociology, (34): 153-179. doi: 10.1146/annurev.soc.34.040507.134608. Accessed February 5, 2016.

Bloemraad, Irene, and Karen Schönwälder. 2013. " Immigrant and Ethnic Minority Representation in Europe: Conceptual Challenges and Theoretical Approaches", West European Politics, 36:3, 564579. Doi.org/10.1080/01402382.2013.773724. Accessed March 26, 2016.

Boccagni, Paolo. 2012. La Partecipazione politica degli immigrati: dal dibattito internazionale al caso italiano, in Ambrosini Maurizio (a cura di), Governancedelle citta plurali, Milano Franco Angeli. Milano. Italy.

Borket, Maren, and TizianaCaponio. 2010. Introduction: the local dimension of immigration Policymaking, in The Local Dimension of Immigration Policy Making, edited by TizianaCaponio and MarenBorket, Amsterdam, Amsterdam University Press, IMISCOE Reports, 9-32.

Bueker, Catherine Simpson. 2005. "Political Incorporation among Immigrants from Ten Areas of Origin: The Persistence of Source Country Effects", The International Migration Review, 39 (1): 103 140. http://www.jstor.org/stable/27645478. AccessedDecember 21, 2015.

Calise, Mauro. 2010. Il partito personale. I due corpi del leader. Editori Laterza, Bari, Italy.

Caponio, Tiziana. 2006. "Quale partecipazione politica degli stranieri in Italia? Il caso delle consulte elettive dei comuni dell’Emilia Romagna”, IX Convegno internazionale della S.I.S.E.La cittadinanza elettorale, Firenze, 14-15 Dicembre 2006.

Caritas/Migrantes. 2016. Dossier Statistico Immigrazione 2016. Centro Studi e Ricerche IDOS, Rome.

Chaudhary, Ali R. 2016. “Transnational politics and immigrant political participation in Europe",Working Paper, International Migration Institute, University of Oxford, 127:1 22.http://www.imi.ox.ac.uk/publications/transnational-politics-and-political-integration-amongmigrants-in-europe. Accessed March 27, 2016.

Cinalli, Manlio, MarcoGiugni, and AlessandroNai. 2010. "La partecipazione politica e la protesta degli immigrati. Una comparazione del ruolo delle opportunità politiche in nove città europee", Rivista Italiana di Scienza Politica, Anno XL, 3:397-420.

Cingolani, Pietro. 2012"Dentro la Barriera. Vivere e raccontare la diversità nel quartiere". In, Concordia Discors. Convivenza e conflitto nei quartieri di immigrazione, (a cura di) Ferruccio Pastore, Irene Ponzo, 53-83. Carocci, Roma. 
Colombo, Enzo, Lorenzo Domaneschi, and Chiara Marchetti. 2009. Una nuova generazione di italiani. L’idea della cittadinanza tra i giovani figli di immigrati. Franco Angeli. Milano. Italy.

Comune di Padova - Settore Programmazione Controllo e Statistica. 2014. Residenti a Padova con cittadinanza straniera.http://www.padovanet.it.Accessed February 13, 2016.

Dancygier, Rafaela, and Elizabeth N. Saunders. 2006 "A new electorate? Comparing preferences and partisanship between immigrants and natives."American Journal of Political Science, 50 (4): 962981. http://www.princeton.edu/ rdancygi/Publications/DancygierSaundersAJPS.pdf AccessedNovember 18, 2016.

Della Porta, Donatella, and Marco Diani. 1999. Social Movements: An Introduction, Oxford, Basil Blackwell.

de Rooij, Eline A. 2012 "Patterns of Immigrant Political Participation: Explaining Differences in Types of Political Participation between Immigrants and the Majority Population in Western Europe", European Sociological Review, 28 (4): 455-481. DOI:10.1093/esr/jcr010. Accessed March 11, 2016.

Diamanti, Ilvo, Roberto Biorcio, Martina Di Pierdomenico,and Alice Sauro. 2015. 51 Atlante Politico. Indagine Demos\&Pi, per la Repubblica. Rapporto Settembre 2015. http://www.demos.it/2015/pdf/3571ap51_20150912.pdf.Accessed March 27, 2016.

Eurostat. 2014. "Foreign National in EU28" 1 January 2014: Eurostat. http://ec.europa.eu/eurostat/statisticsexplained/index.php/Migration and migrant_population_statistics Accessed March 27, 2016.

Fennema, Meindert, and Jean Tillie. 1999. "Political participation and political trust in Amsterdam. Civic communities and ethnic networks. Journal of Ethnic and Migration Studies, 25 (4): 703-726, DOI:10.1080/1369183X.1999.9976711. Accessed December 21, 2015.

Flick, Uwe. 2009. An Introduction to Qualitative Research. Fourth Edition. SAGE Publications Ltd. London Library of Congress.

Garbaye, Romain. 2004. "Ethnic minority local councillors in French and British cities: Social determinants and political opportunity structures", edited by RinusPenninx, Karen Kraal, Marco Martiniello and Steven Vertovec, Citizenship in European cities. Immigrants, Local Politics and Integration Policies. 39-56.Ashgate, Aldershot.

Glaser, Barney G., and Strauss, Anselm L. 1971, Status passage: A formal Theory. Mill Valley.

Glick Schiller, Nina. 2012. "Situating identities: towards an identities studies without binaries of difference”. Identities, 19.4: 520-532. DOI:10.1080/1070289X.2012.741525. Accessed May 15, 2016.

Gonzales-Ferrer, Amparo, and Laura Morales. 2013. "Do citizenship regimes shape political incorporation? Evidence from four European cities",European Political Science 12: 455-466. Doi:10.1057/eps.2013.15. Accessed December 8, 2016.

Gordon, Milton M. 1964. Assimilation in American life: The role of race, religion and national origins. Oxford University Press, 1964. 
King, Russell, and Nicola Mai. 2009. "Italophilia meets Albanophobia: paradoxes of asymmetric assimilation and identity processes among Albanian immigrants in Italy", Ethnic and Racial Studies, 32 (1): 117-138, DOI: 10.1080/01419870802245034. Accessed November 21, 2015.

Krause,Kristine, and Katharina Schramm. 2011. "Thinking through Political Subjectivity", African Diaspora, 4: 115-134. DOI: 10.1163/187254611X607741. Accessed May 15, 2016.

Just, Aida, and Christopher J. Anderson. 2012. "Immigrants, Citizenship and Political Action inEurope". British Journal of Political Science, 42: 481-509 Doi:10.1017/S0007123411000378. Accessed February 18, 2016.

La Mendola, Salvatore. 2009. “Centrato Aperto. Dare vita a interviste dialogiche”, Utet Università, Italy.

Link, Bruce G., and Jo C. Phelan. 2001. "Conceptualizing stigma."Annual review of Sociology, 27: 363385. http://www.jstor.org/stable/2678626, Accessed November 3, 2015.

Lister, Ruth, NoelSmith, Sue Middleton, and Lynne Cox. 2003. "Young People Talk about Citizenship: Empirical Perspectives on Theoretical and Political Debates", Citizenship Studies, 7 (2): 235-253, DOI: 10.1080/1362102032000065991. Accessed December 1, 2015.

Mantovan, Claudia. 2013. "Cohesion without participation: immigration and migrants' associations in Italy”, Patterns of Prejudice, 47 (3): 253-268, DOI:10.1080/0031322X.2013.797172. Accessed February 15, 2016.

Markova, Ivana. 2008. “A Dialogical perspective of Social Representations of Responsibility”. In Meaning in Action. Constructions, Narratives and Representations, edited byToshio Sugiman, Kenneth J. Gergen, Wolfgang Wagner and Yoko Yamada253-270. Library of Congress, 2008, Japan.

Martiniello, Marco. 2005. "Political Participation, Mobilisation and Representation of Immigrants and their Offspring in Europe". Willy Brandt Series of Working Papers in International Migration and Ethnic Relations, 1/05, Malmö.

- 2006. "Political participation, mobilisation and representation of immigrants and their offspring in Europe", In Migration and Citizenship: Legal Status, Rights and Political Participation, edited by Rainer Bauböck, IMISCOE (International Migration, Integration and Social Cohesion), 83112. Amsterdam University Press, Amsterdam.

MIPEX. 2015. “Integration Policies: who benefits?” In Migrant Integration Policy Index: MIPEX publications. http://mipex.eu/sites/default/files/downloads/files/mipex-2015-book-a5.pdf. Accessed March 27, 2016.

Mollenkopf, John. 2013. "Dimensions of Immigrant Political Integration". In Outsiders No More?: Models of Immigrant Political Incorporation, edited byJennifer,Hochschild, Jacqueline Chattopadhyay, Claudine Gay and Michael Jones-Correa, 107-118.Oxford University Press.

Morales, Laura, and Marco Giugni. 2011. Social Capital, Political Participation and Migration in Europe. Making Multicultural Democracy Work? Palgrave Macmillan.

Pero', Davide, and JohnSolomos. 2010. "Introduction Migrant Politics and Mobilization: Exclusion, Engagements, Incorporation”, Ethnic and Racial Studies, 33(1): 1-18. Doi: 10.1080/01419870903418944. AccessedNovember 5, 2016. 
Perocco, Fabio. 2003. L'apartheid Italiano. In Gli Immigrati in Europa. Disuguaglianze, Razzismo, Lotte, edited by Pietro Basso and Fabio Perocco, 211-233. Franco Angeli, Milano, Italy

Pilati, Katia. 2010. "Disuguaglianze strutturali e partecipazione politica degli immigrati filippini, egiziani ed equadoriani a Milano", Polis, XXIV:257-285.

Pizzorno, Alessandro. 1986. "Some Other Kinds of Otherness: A Critique of 'Rational Choice' Theories", in Development, Democracy, and the Art of Trespassing: Essays in Honor of Albert O.

Hirschmanedited by, Alejandro Foxley, Michael S. McPherson and Guillermo O'Donnell, 355-73, Notre Dame: University of Notre Dame Press.

Putnam, Robert D. 2000. Bowling Alone, The Collapse and Survival of American Community, Simon \& Schuster.

Romania, Vincenzo. 2004. Farsi passare per italiani. Strategie di mimetismo sociale, Carocci, Roma, Italy

Sandovici, Maria Elena, and Ola Listhaug.2010."Ethnic and linguistic minorities and political participation in Europe."International Journal of Comparative Sociology, 51.1(2): 111-136. Accessed March 23, 2016.

Shkopi, Eriselda, and Zana Vathi. 2016. "A Case of Bottom-Up, Slow, and Ongoing Political Integration? Naturalised Albanians in Italy", Working Paper No. 88, University of Sussex, Sussex Centre for Migration Research. https://www.sussex.ac.uk/webteam/gateway/file.php?name=mwp88.pdf\&site=252 Accessed December 20, 2016.

Togeby, Lise. 1999. "Migrants at the Polls: An Analysis of Immigrant and Refugee Participation in Danish Local Elections”, Journal of Ethnic and Migration Studies, 25 (4): 665-84.

Turner, Eric. 2012, “TheGrilliniin Italy: New Horizons for Internet-based Mobilization and Participation", Social Movement Studies, 12 (2): 214-220, DOI: 10.1080/14742837.2012.704177. Accessed May 15, 2016.

Vathi, Zana. 2012. "Local identities, identification and incorporation of Albanian immigrants in Florence, Modern Italy, 17 (1): 51-67, DOI:10.1080/13532944.2010.524638. Accessed November 5, 2015.

-2015. Migrating and settling in a mobile word. Albanian migrants and their children in Europe. IMISCOE Research series. Springer Open.

Verba, Sidney, Kay LehmanSchlozman, and Henry E. Brady. 1995. Voice and equality: Civic voluntarism in American politics. Cambridge, MA: Harvard University Press.

Zincone, Giovanna. 2006. Familismo legale - Come (non) diventare italiani, (a cura di), Editori Laterza, Bari. 
Published by the Centre for European Studies at Carleton University, Ottawa, Canada Available online at: journals.carleton.ca/rera/index.php/rera

RERA is an electronic academic peer-reviewed journal. Topics relate to the European Union, its Member States, the former Soviet Union, and Central and Eastern Europe. The journal is a joint project supported by the Canada-Europe Transatlantic Dialogue - a cross-Canada research network supported by the Social Sciences and Humanities Research Council of Canada (SSHRC) - along with the Institute of European, Russian and Eurasian Studies (Carleton University) and its associated research unit, the Centre for European Studies.

RERA aims to provide an accessible forum for research, to promote high standards of research and scholarship, and to foster communication among young scholars.

\section{Contact:}

Carleton University

The Centre for European Studies

1103 Dunton Tower

1125 Colonel By Drive

Ottawa, ON K1S 5B6

Canada

Tel: +01 613 520-2600 ext. 3117; E-mail: rera-journal@ carleton.ca

\section{Creative Commons License}

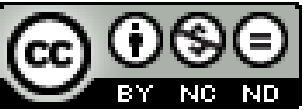

creativecommons.org/licenses/by-nc-nd/3.0

This Working Paper is licensed under a Creative Commons Attribution-Non-CommercialNo Derivs 3.0 Unported License (CC BY-NC-ND 3.0).

Articles appearing in this publication may be freely quoted and reproduced, provided the source is acknowledged. No use of this publication may be made for resale or other commercial purposes.

ISSN: 1718-4835

(C) 2017 The Author(s) 